\title{
Expression of Estrogen Receptor $\alpha$ and $\beta$ in Rat Astrocytes in Primary Culture: Effects of Hypoxia and Glucose Deprivation
}

\author{
M. D. AL-BADER ${ }^{1}$, S. A. MALATIALI ${ }^{1}$, Z. B. REDZIC ${ }^{1}$ \\ ${ }^{1}$ Department of Physiology, Faculty of Medicine, Kuwait University, Kuwait
}

Received March 3, 2011

Accepted September 1, 2011

On-line October 12, 2011

\begin{abstract}
Summary
Estrogen replacement therapy could play a role in the reduction of injury associated with cerebral ischemia in vivo, which could be, at least partially, a consequence of estrogen influence of glutamate buffering by astrocytes during hypoxia/ischemia. Estrogen exerts biological effects through interaction with its two receptors: estrogen receptor alpha $(\mathrm{ERa})$ and estrogen receptor beta (ER $\beta)$, which are both expressed in astrocytes. This study explored effects of hypoxia and glucose deprivation (HGD), alone or followed by $1 \mathrm{~h}$ recovery, on ERa and ER $\beta$ expression in primary rat astrocyte cultures following $1 \mathrm{~h}$ exposure to: a) $5 \%$ $\mathrm{CO}_{2}$ in air (control group-CG); b) $2 \% \mathrm{O}_{2} / 5 \% \mathrm{CO}_{2}$ in $\mathrm{N}_{2}$ with glucose deprivation (HGD group-HGDG); or c) the HGDG protocol followed by $1 \mathrm{~h}$ CG protocol (recovery group-RG). ERa mRNA expression decreased in HGDG. At the protein level, full-length ERa (67 kDa) and three ERa-immunoreactive protein bands (63, 60 and $52 \mathrm{kDa}$ ) were detected. A significant decrease in the $52 \mathrm{kDa}$ band was seen in HGDG, while a significant decrease in expression of the full length ERa was seen in the RG. ER $\beta$ mRNA and protein expression (a $54 \mathrm{kDa}$ single band) did not change. The observed decrease in ERa protein may limit estrogenmediated signalling in astrocytes during hypoxia and recovery.
\end{abstract}

\section{Key words}

Astrocytes • Estrogen receptor • Hypoxia • Glucose deprivation • Ischemia • Brain

\section{Corresponding author}

Z. Redzic, Department of Physiology, Faculty of Medicine, Kuwait University, P.O. Box 24923 Safat, 13110, Kuwait. Fax: +965 25338937. E-mail: redzic@hsc.edu.kw

\section{Introduction}

Mild to moderate reduction in cerebral blood flow, as seen in the penumbra during transient focal cerebral ischemia or in the whole brain during hypoperfusion, could trigger events through several signaling pathways, including activation of AMPactivated protein kinases ( $\mathrm{Li}$ and McCullough 2010), which could lead to apoptotic cell death (Hossmann 2008). A well established theory suggests a role for glutamate accumulation in the interstitial fluid (Mergenthaler et al. 2004), which binds to ionotropic receptors, causing an increase in $\mathrm{Ca}^{++}$entry into the cells (Broughton et al. 2009) and facilitating an accumulation of intracellular $\mathrm{Ca}^{++}$that triggers the intrinsic apoptotic pathway (Dirnagl et al. 1999). Thus, the amount of glutamate released in the early stages of an ischemic event could be of considerable importance in determining the extent of apoptotic cell death in the penumbra (Hertz 2008). Astrocytes play a key role in buffering extracellular glutamate during hypoxia/ischemia (Hertz 2008) because these cells have a considerable potential to take up glutamate from the extracellular space through the action of glutamate transporters (Chao et al. 2010) and can accumulate glutamate for a considerable time during an ischemic event (Haberg et al. 1998, 2001).

Estrogen can influence glutamate buffering by astrocytes during brain ischemia but the results are conflicting: administration of estrogen to rat astrocytes in primary culture significantly increased expression of glutamate transporters at mRNA and protein levels and this was accompanied by elevated l-glutamate uptake (Sato et al. 2003). However, another study revealed that estrogens down-regulate l-glutamate uptake activity of 
astrocytes via membrane $\mathrm{ER} \alpha$ (Billeci et al. 2008). Most studies support a role for estrogen replacement therapy in the reduction of ischemic brain injury (Billeci et al. 2008). Female gerbils experienced less severe brain damage following severe incomplete hemispheric ischemia produced by unilateral carotid occlusion than did male gerbils (Hall et al. 1991). Exogenous administration of $17 \beta$-estradiol reduces infarct volume following middle cerebral artery occlusion (MCAO) in ovariectomized female rats (Dubal et al. 1998, Rusa et al. 1999). Exogenous estradiol, when administered at the onset of MCAO, also showed to be protective in male rats (Toung et al. 1998). The doses of $17 \beta$-E2 used in these studies did not influence cerebral blood flow, implying that the neuroprotective effect of 17/-E2 occurs directly at the level of the brain rather than involving the vasculature (Rusa et al. 1999).

Estrogen regulates gene expression through interaction with estrogen receptor alpha $(E R \alpha)$ and estrogen receptor beta (ER $\beta$ ), which are both expressed in the brain (Shughrue et al. 1997). ERs are selectively expressed in some types of neurons, like Purkinje cells (Ikeda and Nagai 2006) and inhibitory interneurons in hippocampus, but not in the pyramidal neurons or in granule cells (Prewitt and Wilson 2008). Estrogen interacts directly with apoptotic signalling processes in neurons (Meda et al. 2000). Astrocytes express both ER $\alpha$ (Huppmann et al. 2008, Bondar et al. 2009, Yi et al. 2009) and ER $\beta$ (Huppmann et al. 2008) receptors. However, no data exist so far regarding the responses of these receptors upon the conditions that mimic conditions during short cerebral ischemia and recovery. The aim of our study was to assess the expression of ER $\alpha$ and ER $\beta$ in rat astrocytes in primary culture at the transcript level, by real time-polymerase chain reaction (ReT-PCR), and at the protein level by immunoblotting and to explore changes in the expression of ER $\alpha$ and ER $\beta$ after $1 \mathrm{~h}$ HGD alone or followed by 1 hour recovery.

\section{Methods}

This study was approved by the Medical Research Council of the Faculty of Medicine, Kuwait University. Animals were maintained and handled in the Animal House, Health Science Centre, and all procedures were conducted in accordance with the animal care guidelines in this institution and in accordance with the Guidelines on Laboratory Animal Care.

\section{Chemicals and solutions}

Two days old female Sprague Dawley pups were used to initiate primary cultures of astrocytes; cortices from four pups were used to initiate primary cultures in four $25 \mathrm{~cm}^{2}$ flasks or in four 6-well plates. The following solutions were used: (a) phosphate buffered saline (PBS), containing (mmol/l): $\mathrm{NaCl} 136.9, \mathrm{KCl} 2.7, \mathrm{KH}_{2} \mathrm{PO}_{4} 1.5$, $\mathrm{Na}_{2} \mathrm{HPO}_{4}$ 7.7, pH 7.4; (b) tissue buffer, which was $\mathrm{Ca}^{++}$ and $\mathrm{Mg}^{++}$free Hank's Balanced Salt Solution (GIBCO, Carlsbad, USA) containing (mmol/1) $\mathrm{NaCl} \mathrm{140,} \mathrm{KCl} 5.4$, $\mathrm{Na}_{2} \mathrm{HPO}_{4}$ 0.67, $\mathrm{KH}_{2} \mathrm{PO}_{4} 0.5$, glucose 17 , sucrose 12 , HEPES 20 and penicillin/gentamicin $100 \mathrm{U} / \mathrm{ml}$; pH 7.4; (c) Dulbecco's modified Eagle's medium (DMEM) containing $7 \mathrm{mM}$ D-glucose, L-glutamine and $\mathrm{Na}^{+}$pyruvate. This medium was prepared by adding an appropriate amount of a high glucose DMEM (GIBCO, catalogue number 11995-040) and $10 \%$ (v/v) Fetal Calf Serum (FCS) (Invitrogen) to a low glucose DMEM (GIBCO, 11885-084); (d) low glucose, pyruvate-free DMEM, containing L-glutamine and 1.5 mM D-glucose, which was prepared by adding appropriate amount of a high glucose, pyruvate-free DMEM (Gibco, 31053-028) and $10 \%$ FCS to a glucose and pyruvate free DMEM (Gibco, 11966-025). It also contained $10 \mathrm{mM}$ 2-deoxyglucose (2-DG) (Sigma), an analogue of D-glucose that cannot be metabolized beyond the 2-deoxy-glucose 6-phosphate, thereby competitively inhibiting glycolysis (e) homogenisation buffer, containing $10 \mathrm{mM}$ Tris, $1.5 \mathrm{mM}$ EDTA, $10 \%(\mathrm{v} / \mathrm{v})$ glycerol, $1 \mu \mathrm{g} / \mathrm{ml}$ leupeptin, $100 \mu \mathrm{g} / \mathrm{ml}$ bacitracin, and $1 \mu \mathrm{g} / \mathrm{ml}$ pepstatin.

Reverse-transcription PCR buffers, enzymes and reagents were supplied by Invitrogen. Real time PCR (ReT-PCR) reagents were purchased from Applied Biosystems, USA. A rabbit polyclonal antibody that recognized a peptide corresponding to amino acids 1-150 of human ER $\beta$ (H-150; Santa Cruz Biotechnology, Inc., CA, U.S.A), which cross-reacts with rat ER $\beta$ (Qiu et al. 2005) and a mouse monoclonal anti-ER $\alpha$ raised against the amino acid residues 151-165 of human ER $\alpha$ (MAB463, Millipore, Ann Arbor, MI, U.S.A.) that crossreacts with rat ER $\alpha$ (Ali et al. 1993, Jesmin et al. 2002) were used. For the detection of actin, a mouse monoclonal IgG1 anti-human actin antibody was used (Millipore, USA). PVDF membranes were obtained from Amersham Biotech (Buckinghamshire, UK). General laboratory chemicals were purchased from Merck (Dagenham, U.K.) and all fine chemicals were obtained from Sigma (Poole, U.K.). 
Treatment of animals, tissue extraction and initiation of culture

A total of thirty 1-2 day old Sprague-Dawley rats were used in this study. Efforts were made to reduce the number of animals used and to minimize animal suffering. Rats were sacrificed by cervical dislocation, skull was opened, dura mater was dissected and brain immersed in ice-cold tissue buffer. The remaining meninges and choroid plexuses were carefully removed from brain surface under a magnifying glass, cerebral cortices were separated and the white matter carefully removed. The remaining cortices were kept in tissue buffer on ice.

Primary cultures were produced as described earlier (Dolman et al. 2005). Briefly, the isolated tissue was incubated into warm $\left(37^{\circ} \mathrm{C}\right)$ tissue buffer containing $0.25 \%$ trypsin (Gibco) for $30 \mathrm{~min}$. Trypsin was inactivated by adding a serum-containing DMEM, tissue was triturated through a pipette tip for $1 \mathrm{~min}$ and the cell suspension was filtered through 80 micron cell strainer (BD Falcon, San Jose, USA). The cell suspension was centrifuged at $600 \mathrm{x} \mathrm{g}$ for $5 \mathrm{~min}$, the pellet was resuspended in DMEM and placed in $25 \mathrm{~cm}^{2}$ cell culture flasks (Nunc, Rochester, NY, USA) pre-treated with poly-1-lysine $(0.01 \%)$ for $15 \mathrm{~min}$. The cell cultures were incubated at $37{ }^{\circ} \mathrm{C}$ in water saturated air with $5 \% \mathrm{CO}_{2}$ and medium was changed every 2 days.

Primary cultures were purified as described by Rist et al. (1997). Briefly, at sub-confluence, cell contaminants on the top of the monolayer were separated from astrocytes by shaking for $24 \mathrm{~h}$ at $110 \mathrm{rpm}$ at $37^{\circ} \mathrm{C}$ on a Stuart mini orbital shaker (Stuart Scientific, Stone, U.K.) at $37{ }^{\circ} \mathrm{C}$. Further purification of the cell cultures was achieved at confluence (day 11-12 after plating) by adding cytosine arabinoside $(0.01 \mathrm{mM})$ to the culture medium for 3-4 days. Since at this stage astrocytes reach confluence, they do not divide further, so cytosine arabinoside affects only contaminating dividing cells and no effects of this treatment on astrocytes morphology could be observed under the phase contrast microscopy, which was in agreement with the results reported before (Rist et al. 1997). Cells were used for experiments $18-20$ days after seeding. It has been shown earlier that this procedure produces astrocytes primary cultures, with reported purity of $>90 \%$ (Rist et al. 1997) and $>95 \%$ (Romero et al. 1995), which was estimated counting cells that were stained with antibodies for glial fibrillary acidic protein (GFAP) (Romero et al. 1995, Rist et al. 1997) and high expression of GFAP mRNA (Dolman et al. 2005).

\section{Treatment of the cells and experimental groups}

In this study primary cultures were divided into three experimental groups: control group $(\mathrm{CG})$ : primary cultures were incubated in DMEM and exposed to $5 \%$ $\mathrm{CO}_{2}$ in air during the course of experiment; hypoxia and glucose deprivation (HGDG) group: primary cultures were transferred into a handmade transparent glove-box chamber (manufactured in the Health Science Centre workshop) with $2 \% \mathrm{O}_{2}, 5 \% \mathrm{CO}_{2}$ in $\mathrm{N}_{2}$; the composition of gases was constantly monitored by a NormocapOxy gas analyzer (Datex-Ohmeda, GE Health Care); cultures were washed with PBS and low glucose, pyruvate-free DMEM with $10 \mathrm{mM}$ 2-DG was added to primary cultures. Cells were kept under these conditions for $1 \mathrm{~h}$. All solutions were kept in the chamber for $12 \mathrm{~h}$ prior to experiments in order to equilibrate gases; recovery groups (RG): primary cultures were exposed to the same protocol as described for the HGDG and then were exposed to the same conditions as flasks from the $\mathrm{CG}$ for $1 \mathrm{~h}$.

\section{Expression of ER $\alpha$ and ER $\beta$ at the transcript level \\ $R N A$ extraction and reverse transcription}

At the end of each protocol, total RNA was extracted with Trizol (Invitrogen) and dissolved in diethylpyrocarbonate-treated water at $55^{\circ} \mathrm{C}$. RNA concentrations were determined by absorbance at $260 \mathrm{~nm}$ and $2 \mu \mathrm{g}$ portions were used for reverse transcription. Intron-spanning primers were used in the study that excluded interference from genomic DNA in the results; however, all RNA samples were treated with DNAase, 4 units/sample (Invitrogen, Carlsbad, USA) prior to reverse transcription. Two $\mu \mathrm{g}$ portions were used for firststrand cDNA synthesis, which was performed with MuMLV reverse transcriptase (Invitrogen) using random hexamers, according to the manufacturer's instructions (RT+ samples). Negative controls (RT- samples) were processed under the same conditions, with the reverse transcriptase replaced with water.

\section{Real-time PCR}

The ReT-PCR reaction was carried out in a ReTPCR system (Applied Biosystems, model 7500), using the following gene expression assays, which had intronspanning primers and hydrolysis probes labeled with 6-carboxyfluorescein (FAM) as a reporter dye and 6-carboxy-tetramethyl-rhodamine (TAMRA) as a quencher dye: assay ID Rn01430446_m1, expected amplicon length $73 \mathrm{bp}$ for ER $\alpha$, assay ID Rn00562610_m1, expected amplicon length 89 bp for 
ER $\beta$ and assay ID Hs99999901-sl, expected amplicon length $187 \mathrm{bp}$ for $18 \mathrm{~S}$ ribosomal RNA. The PCR reactions were prepared using the TaqMan universal master mix (Applied Biosystems) and were carried out in a 96-well plate that was sealed with an adhesive transparent foil, employing the thermal profile that was suggested by the manufacturer: $2 \mathrm{~min}$ at $50^{\circ} \mathrm{C}$ ( 1 cycle); $10 \mathrm{~min}$ at $95{ }^{\circ} \mathrm{C}(1 \mathrm{cycle})$ and then $15 \mathrm{~s}$ at $95{ }^{\circ} \mathrm{C}$ and $1 \mathrm{~min}$ at $60{ }^{\circ} \mathrm{C}$ for 40 cycles. In some cases, a $10 \mu \mathrm{l}$ sample of the PCR product was analyzed by electrophoresis on a $2 \%$ agarose gel that contained ethidium bromide in order to verify that product sizes were as expected.

In some cases, a series of dilutions of cDNA was made (2-64 folds) and then ReT-PCR reactions were carried out as outlined above. The obtained $\mathrm{Ct}$ values for $\mathrm{ER} \alpha, \mathrm{ER} \beta$ and $18 \mathrm{~S}$ were then plotted against the $\log$ dilution and the coefficient of linearity and the slope were calculated and efficiencies of the PCR were estimated using the following equation (Pfaffl 2001):

$$
\mathrm{E}=10^{-1 / \text { slope }}
$$

Under theoretically ideal circumstances, in every PCR cycle the amount of product should be doubled giving the ideal efficiency of 2.00 .

The relative gene expression was calculated using the efficiency corrected calculation model for multiple samples and based on one reference gene (Pfaffl 2001). All samples were done in duplicates and the $\Delta \mathrm{Ct}$ value for each sample was determined by subtracting the average $18 \mathrm{~S} \mathrm{Ct}$ value from the average ER $\alpha$ or ER $\beta \mathrm{Ct}$ value. The fold change was then calculated as:

$$
\text { Ratio }=\frac{\left(\mathrm{E}_{\text {target }}\right)^{\Delta \mathrm{Ct}(\text { control-sample })}}{\left(\mathrm{E}_{\text {reference }}\right)^{\Delta \mathrm{Ct} \text { (control-sample })}}
$$

This equation expresses fold change (ratio) of ER genes in the HGDG and RG versus the $C G$ in comparison to the $18 \mathrm{~S}$ gene. $\mathrm{E}_{\text {target }}$ and $\mathrm{E}_{\text {reference }}$ are the efficiencies of target and reference gene transcripts, respectively. In every experiment, 3 flasks for the same batch were exposed to experimental protocols (one in each group: CG, HGDG, RG); the ratio was calculated for the HGDG, RG; finally, the average fold change \pm S.D. in the HGDG and the fold change in the RG (both relative to the $\mathrm{CG}$ ) were calculated from 3-4 different batches using the equation 2 .
Expression of ER $\alpha$ and ER $\beta$ at the protein level

Cellular monolayers from CG, HGDG and RG were washed twice with ice-cold saline, detached from the surface by Trypsin-EDTA solution and then homogenized in ice-cold homogenization buffer using a Polytron homogenizer, to yield a $5 \%(\mathrm{w} / \mathrm{v})$ homogenate.

Twenty $\mu \mathrm{g}$ of protein was loaded per lane, and separated using $7.5 \%$ SDS-PAGE. The monoclonal ER $\alpha$ antibody was used at a dilution of 1:500 in $10 \%$ non-fat dry milk in Tris Buffer Saline-Tween20 (TBS-T, containing $20 \mathrm{mM}$ Tris, $137 \mathrm{mM} \mathrm{NaCl}$, pH 7.6 and $0.1 \%$ $\mathrm{v} / \mathrm{v}$ Tween 20), the polyclonal ER $\beta$ antibody was used at a dilution of $1: 100$ in $10 \%$ non-fat dry milk in TBS-T and the anti-actin antibody was used at a dilution of 1:50,000 in $5 \%$ non-fat dry milk in TBS-T. Western blot analysis and immunodetection of total ER proteins together with analysis of protein sizes was performed as described earlier (Al-Bader et al. 2008). In preliminary experiments, the primary antibody was omitted and filters were incubated with secondary antibody only. No bands were detected with this antibody. Once membranes were probed with the ER antibodies, they were stripped and reprobed with anti-actin antibody.

\section{Statistical analysis}

Data was tested for statistical significance using unpaired T-test (Epicalc 2000). In some cases, as indicated in the Results section, a difference between the obtained $\mathrm{Ct}$ values in experimental groups was tested by ANOVA.

\section{Results}

Effect of hypoxia and glucose deprivation, and recovery on the expression of ERs at the transcript level

A plot of log dilution against the $\mathrm{Ct}$ values for each pair of primers is shown in Figure 1. Those data points revealed a linear increase of $\mathrm{Ct}$ values with the Pearson's coefficient $r$ being $0.81,0.85$ and 0.82 for $E R \alpha$, ER $\beta$ and $18 \mathrm{~S}$ ribosomal RNA, respectively. The slopes of the corresponding lines were estimated and the PCR efficiencies, calculated using equation 1, were 2.48, 2.03 and 1.93 for $\mathrm{ER} \alpha, \mathrm{ER} \beta$ and $18 \mathrm{~S}$ ribosomal RNA respectively.

Table 1 shows the estimated average $\mathrm{Ct}$ values of ERs in rat astrocytes in the CG, HGDG group and RG. The $\mathrm{Ct}$ values in all negative controls (RT- samples) were above 40 (not shown). Initially, three housekeeping genes were used: glyceraldehyde 3-phosphate dehydrogenase, 


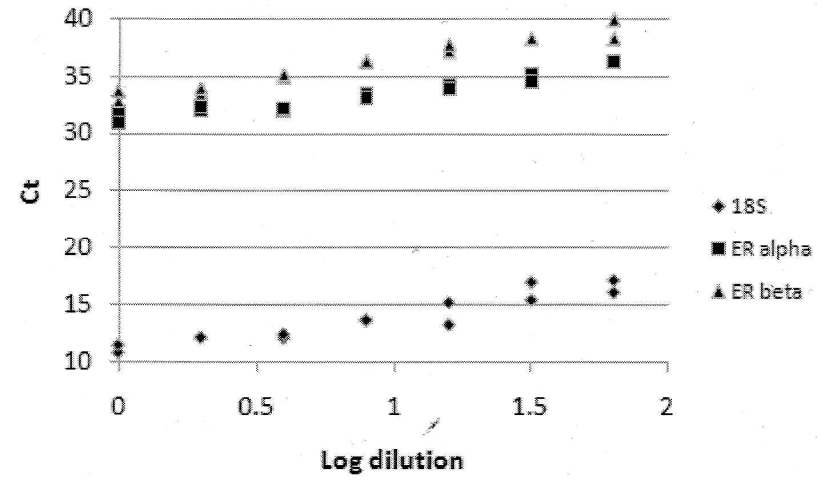

Fig. 1. Validation of the method for fluorescence-based quantitative real-time PCR. Titration curves were obtained by using CDNA to create a series of dilutions, from $1 \mathrm{X}$ (no dilution) to $64 \mathrm{X}$ dilution. Then the quantitative real-time PCR was run and log dilutions plotted against the obtained quantification cycle (Ct) values. Each $\mathrm{Ct}$ value was estimated as an average from 2 replicates and each point in the Figure represents mean \pm S.E. from 3 separate cDNA samples. These data were also used to estimate the efficiency $(E)$ of the reaction for each gene of interest.

beta actin and $18 \mathrm{~S}$ ribosomal RNA. There was no significant difference in the obtained $\mathrm{Ct}$ values between the CG, HGDG and RG for either of those genes ( $p>0.05$ by ANOVA); however, the intra-essay and inter-essay variability, calculated for each gene as explained by Pfaffl (2001), revealed that 18S ribosomal RNA had the most consistent expression in all experimental groups. Therefore, this RNA was used for calculations of the relative expression of ER mRNAs and the $\mathrm{Ct}$ values in $\mathrm{RT}+$ samples are shown in Table 1.

There are several splice variants of ER $\alpha$ mRNA in primates and mice, but no known splice variants in the rat brain; there are four known splice variants of $\operatorname{ER} \beta$ in the rat brain: ER $\beta 1$, ER $\beta 2$, ER $\beta 1 \delta 3$, and ER $\beta 2 \delta 3$ (Petersen et al. 1998, Price et al. 2000). However, there were no splice variants or single-nucleotide polymorphism positions documented in transcript and single-nucleotide polymorphism databases in the regions of the genes corresponding to the portions of the cDNA to be amplified in this study according to the ENSEMBL entries. Thus, use of intron-spanning primers could not affect the quantification data in this study.

The obtained data from the $\mathrm{CG}$ indicated that mRNAs encoding ER $\alpha$ and $\operatorname{ER} \beta$ were $10^{4}$ and $10^{6}$ fold less abundant than $18 \mathrm{~S}$ ribosomal RNA, respectively and that mRNA encoding ER $\beta$ was $\sim 10^{2}$ fold more abundant than mRNA encoding ER $\alpha$. The obtained fold-change values indicated that HGD protocol caused a $50 \%$ decrease in the amount of mRNA for ER $\alpha$, when compared to the $\mathrm{CG}$, while the amount of mRNA for ER $\beta$ did not change. In the RG, the amount of mRNAs for ER $\alpha$ and for ER $\beta$ did not change when compared to the CG.

Effect of hypoxia, glucose deprivation and recovery on the expression of ERs at the protein level

Immunoblots of the astrocyte protein extracts revealed the presence of $E R \alpha$ and $E R \beta$ at the protein level. Rat beta actin, which was used as an internal control and to prove equal loading of protein samples, migrated with mobility comparable to an apparent size of $42 \mathrm{kDa}$ (Fig. 2A).

In addition to the full length $\mathrm{ER} \alpha$, three splice variants (so-called $E R \alpha$-inmmunoreactive proteins) have been detected in rat earlier; they migrated during electrophoresis with apparent molecular weights from $\sim 50 \mathrm{kDa}$ to $\sim 65 \mathrm{kDa}$ (Pasqualini et al. 2001). This finding was also confirmed in later studies that detected that ER $\alpha$ in the rat brain and in astrocytes existed as the full length $\mathrm{ER} \alpha$ (apparent MW 66-67 kDa) and at least one ER $\alpha$-inmmunoreactive protein with apparent MW of 52

Table 1. Expression of ERa and ERß in rat astrocytes in primary culture and the effects of hypoxia and glucose deprivation treatment and recovery on that expression.

\begin{tabular}{lcccccc}
\hline & \multicolumn{2}{c}{ CG } & \multicolumn{2}{c}{ HGDG } & \multicolumn{2}{c}{ RG } \\
\cline { 2 - 7 } & $\mathbf{C t} \pm$ S.E. & $\mathbf{E}^{\text {-Ct }} \pm$ S.E. $\left(\times 1 \mathbf{~ 1 0}^{\mathbf{1 2}}\right)$ & $\mathbf{C t} \pm$ S.E. & Fold change & Ct \pm S.E. & Fold change \\
\hline $18 S$ & $12.99 \pm 0.03$ & $195.99 \pm 3.35 \times 10^{6}$ & $13.62 \pm 0.68$ & & $13.04 \pm 0.02$ & \\
$E R \alpha$ & $29.63 \pm 0.43$ & $2.5 \pm 0.9$ & $30.69 \pm 0.33$ & $0.49 \pm 0.15$ & $28.81 \pm 0.12$ & $0.95 \pm 0.28$ \\
$E R \beta$ & $31.55 \pm 0.47$ & $238 \pm 88$ & $31.57 \pm 1.11$ & $1.58 \pm 0.38$ & $30.74 \pm 0.40$ & $1.40 \pm 0.83$ \\
\hline
\end{tabular}

Data were obtained from 3-4 different samples for ERa and ER $\beta$ and from 6-8 samples for 18S RNA; each sample represented cDNA from one flask. Ct value for a sample was calculated as average from 2 replicates of one sample and $\Delta \mathrm{Ct}$ values for genes of interest and for the housekeeping gene were estimated. The linear form of the Ct values was corrected for the reaction efficiency, and is presented as $\mathrm{E}^{-\mathrm{ct}}$. The $\mathrm{Ct}$ values were used to estimate the fold change in the target genes for each sample (see the Method section), normalized to $18 \mathrm{~S}$ ribosomal RNA and relative to the expression in the control group and the fold change values are presented as mean \pm S.D. 
A

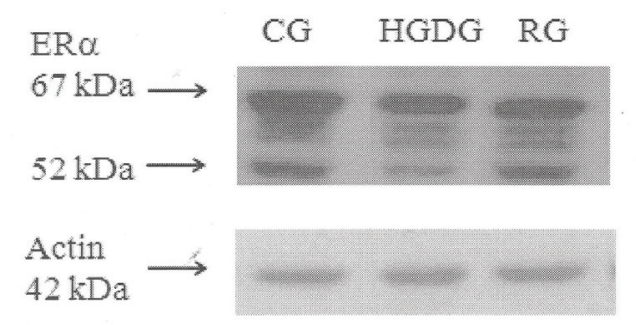

B

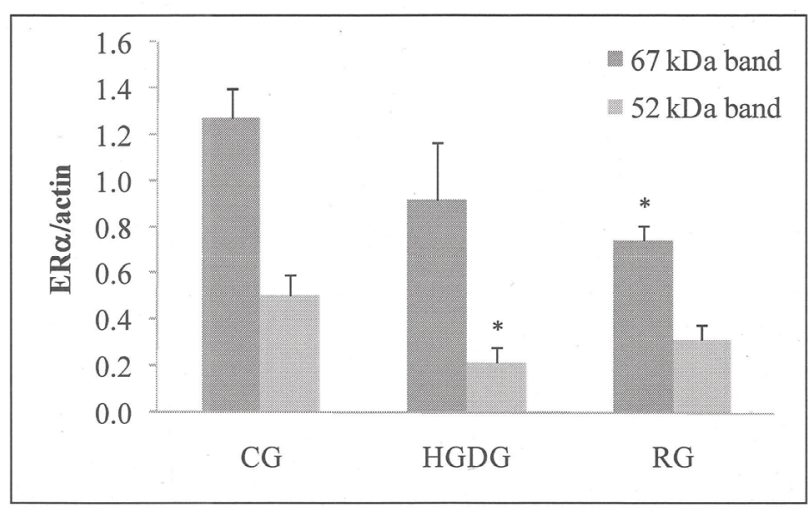

Fig. 2. Expression of ERa protein in rat astrocytes. A mouse monoclonal anti-ERa antibody raised against the amino acid residues $151-165$ was used; $20 \mu \mathrm{g}$ of protein was loaded on $7.5 \%$ SDS-polyacrylamide gels. (A) Representative Western blot for ERa and actin; the calculated size of the band is indicated on the left-hand side of the gel. Bands corresponding to $\sim 67 \mathrm{kDa}$ and $52 \mathrm{kDa}$ molecular weight were detected for ERa. (B) Protein expression profile: ERa protein was expressed relative to actin. Results shown are mean \pm S.E.M. $(n \geq 3)$; there was a significant decrease in the expression of the $67 \mathrm{kDa}$ band between CG and RG $(p=0.01)$ and a significant decrease in expression of the $52 \mathrm{kDa}$ band between CG and HGDG $(p<0.05)$.

kDa (Bondar et al. 2009). In our study, immunoblotting using primary antibodies against ER $\alpha$, revealed presence of two major bands in astrocytes that corresponded to the full length $\mathrm{ER} \alpha(\sim 67 \mathrm{kDa}$ band) and a $52 \mathrm{kDa} \mathrm{ER} \alpha-$ inmmunoreactive protein (Fig. 2A). In addition to those, two minor ER $\alpha$-inmmunoreactive protein bands that migrated with apparent MW of $\sim 60 \mathrm{kDa}$ and $63 \mathrm{kDa}$ were also detected. HGD protocol caused a significant decrease in the expression of the $52 \mathrm{kDa}$ band compared to the expression in the $\mathrm{CG}$ (Fig. 2B), while the expression of other bands did not change significantly. In the $\mathrm{RG} 1 \mathrm{~h}$ there was a significant decrease in the expression of $67 \mathrm{kDa}$ band when compared to the expression in the $\mathrm{CG}(\mathrm{p}<0.05)$, while the expression other bands did not change.

The predicted MW of a wild type ER $\beta$ was 54 $\mathrm{kDa}$; when primary antibodies against ER $\beta$ were used, presence of a single band that migrated with an apparent
A

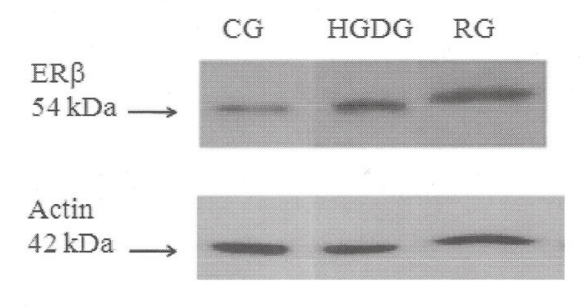

B

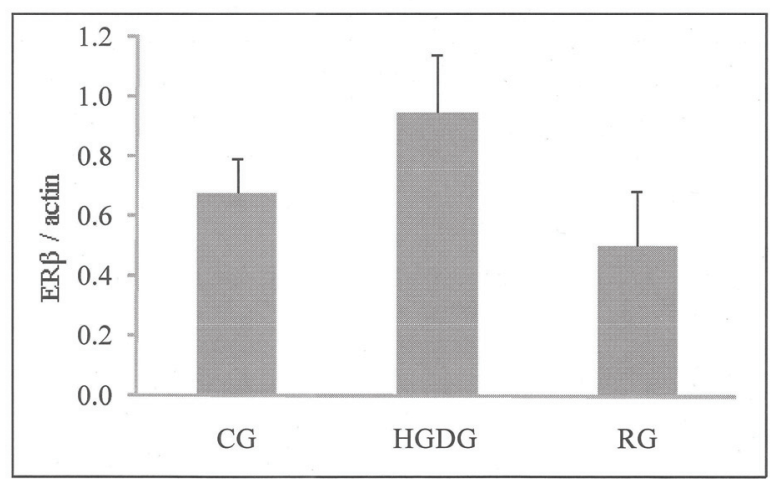

Fig. 3. Expression of $E R \beta$ protein in rat astrocytes. A rabbit polyclonal antibody corresponding to amino acids $1-150$ was used; $20 \mu \mathrm{g}$ of protein was loaded on $7.5 \%$ SDS-polyacrylamide gels. (A) Representative Western blot for ER $\beta$ and actin; the calculated size of the band is indicated on the left-hand side of the gel. One band of apparent molecular weight of $54 \mathrm{kDa}$ was detected for ER $\beta$. (B) Protein expression profile: density of the ERa protein bands were expressed relative to density of the beta actin bands. Results shown are mean \pm S.E.M. ( $n \geq 3)$; no significant change in protein expression was detected.

size of $54 \mathrm{kDa}$ was detected. However, it appears that HGD and recovery protocols did not affect expression of this protein, since the density of this band, relative to density of actin bands, did not differ between HGDG/RG and the CG (Fig. 3B).

\section{Discussion}

Experimental conditions used in this study, hypoxia and glucose deprivation mimic, at least partially, conditions that may occur during hypoperfusion in the brain (i.e. in the penumbra during focal cerebral ischemia or during a transient global cerebral ischemia, like hypotension). Using the same in vitro model, it has been shown that there was $\sim 50 \%$ depletion in cellular ATP in the HGDG after $1 \mathrm{~h}$, which partially reversed after $1 \mathrm{~h}$ recovery; also there was an increase in ATP and adenosine concentration in the cell culture medium, while cell viability did not change and apoptosis was generally rare (Redzic et al. 2010). 
This study revealed that amount of mRNA for both ER $\alpha$ and ER $\beta$ in astrocytes in the CG was low, giving the $\mathrm{Ct}$ values of $\sim 30$, with mRNA for ER $\beta$ being about $10^{2}$ fold more abundant than mRNA for ER $\alpha$. This may indicate a low turnover rate of ERs in astrocytes and is in accordance with a finding that ERs' mRNAs are expressed at very low abundance in rodent neurons (Wilson et al. 2008). It has been shown that deletion of $\mathrm{ER} \alpha$ (in $\mathrm{ER} \alpha$ knockout mice) abolished the protective actions of estradiol in the brain during permanent cerebral ischemia; while in the absence of $\operatorname{ER} \beta$ (in ER $\beta$ knockout mice) the ability of estradiol to protect brain injury during permanent cerebral ischemia was preserved (Dubal et al. 2001). Following brain ischemia ER $\alpha$ was reactivated in rat neurons after 3-6 hours (Dubal et al. 2006). This expression pattern of ER gene expression could be a compensatory mechanism to prevent cell death (Wilson and Westberry 2009). This study revealed changes in the ER $\alpha$ mRNA, which decreased after $1 \mathrm{~h}$ HGD protocol, so it was less abundant in the HGDG than in the CG, while no change in the expression of ER $\beta$ was observed; after the recovery period the amount of mRNA for ER $\alpha$ in was not different from the amount in the CG.

For ER $\alpha$ and $\beta$, a number of variant transcripts have been described (Kuo et al. 2009). However, many of these transcripts are created by skipping internal exons, so they retain the same reading frame as the full-length transcript; thus, only few corresponding variant proteins have been detected (Taylor 2010). It has been shown previously, using anti-full length $\mathrm{ER} \alpha$ antibodies, that $\mathrm{ER} \alpha$ protein existed in rat as full length protein and three splice variants with MW ranging from $\sim 50$ to $\sim 65 \mathrm{kDa}$ (Pasqualini et al. 2001). We found in this study that ER $\alpha$ protein existed in astrocytes as the full length ER $\alpha$, which migrated with apparent MW $67 \mathrm{kDa}$, and an ER $\alpha$ immunoreactive protein, which migrated with apparent MW of $52 \mathrm{kDa}$ and as two additional splice variants, which migrated with apparent MWs of 60 and $63 \mathrm{kDa}$. It was believed initially that ERs were purely nuclear receptors, but it was found that 5-10\% of total cellular ERs existed as proteins with various amount palmitioylated cysteine residues in the plasma membrane and that these proteins mediate membrane-initiated steroid signaling (MISS). MISS depends on coactivation of metabotropic glutamate receptors, causing estradiolinduced calcium influx (Kuo et al. 2009). However, only the full-length ER could bind estradiol and trigger MISS causing increased calcium influx (Bondar et al. 2009). This study showed that $1 \mathrm{~h}$ HGD protocol did not affect the amount of the full length ER $\alpha$; however, after $1 \mathrm{~h}$ recovery, the level of this protein was significantly reduced when compared to control. Since it is believed that estrogen signaling could be protective during cerebral ischemia/hypoxia, our finding indicates a possibility that estrogen could exert limited protective effects on astrocytes during short the recovery phase because of the reduced amount of the full length ER $\alpha$. HGD protocol caused significant reduction in the level of a $52 \mathrm{kDa} E R \alpha$-immunoreactive protein, which is likely to be a splice variant of the full length ER $\alpha$. Also, this protein could be a proteolytic/degradation product, although in this study, every precaution was taken to prevent degradation of proteins, so all procedures were performed at $4{ }^{\circ} \mathrm{C}$ and in the presence of several protease inhibitors.

Little is known about the molecular mechanism that could be involved in a change of ER $\alpha$ expression during HGD and recovery treatments. Hypoxia can alter the amount of mRNA for various proteins via hypoxia inducible factor-1 (HIF-1), so a hypothesis could be established that the observed changes in ER $\alpha$ could be HIF-mediated. HIF- $1 \alpha$ is not found in astrocytes under normoxic conditions due to ubiquitin-proteasomal degradation; however, it was shown that the lack of oxygen stabilizes the $\alpha$-subunit of the transcription factor HIF-1 via inhibition of its degradation. Thus, the level of HIF- $1 \alpha$ in astrocytes in culture increased after oxygen deprivation (Karovic et al. 2007). HIF-1 binds to the ciselements within target genes that include several growth factors, such as erythropoietin (Semenza 2007). There are two possible mechanisms that could link HIF-1 to the ER $\alpha$ downregulation. First, HIF-1 interacts with ER $\alpha$ and this interaction down-regulates the ER $\alpha$ transcriptional activity (Cho et al. 2005) but had no effect on ER $\beta$ transcriptional activity (Yi et al. 2009), which appears to be in accordance with the finding that there was no change in the amount of ER $\beta$ mRNA in the HGDG. Second, it has been shown that insulin receptor substrate2 (IRS-2) is phosphorylated on tyrosine following treatment of cells with erythropoietin (Verdier et al. 1997), an action which was believed to mimic the effects of insulin. It is known that cell signalling via insulin receptor or and epidermal growth factor receptor can decrease ER $\alpha$ mRNA expression (Wilson and Westberry, 2009), which is consistent with findings of this study.

However, due to a short period of HGD and recovery treatments in this study, a decrease in the ER $\alpha$ at the protein level is likely to be due to degradation of 
existing ER $\alpha$, rather than to a reduction in mRNA and a consequent reduction in $\mathrm{ER} \alpha$ translation. It has been shown that hypoxia induced proteasome-dependent downregulation of $\mathrm{ER} \alpha$ (Cho et al. 2006) and direct repression of ER which has been shown in breast cancer cell lines following hypoxia (Cho et al. 2005). Also, it has been shown that ER $\alpha$ is degraded in response to hypoxia and estradiol via a proteasome pathway, which was not seen for the ER $\beta$ (Yi et al. 2009). These data support a hypothesis that a downregulation of ER $\alpha$ at the transcript and at the protein level, which was observed in this study, was induced by HIF-1 -mediated pathways.

Estrogen signalling increased expression of glutamate transporters GLT-1 and GLAST on the mRNA and protein level in rat astrocytes through binding to nuclear estrogen receptors, a process which was accompanied by an increase in glutamate uptake (Pawlak et al. 2005). Therefore, a downregulation in ER $\alpha$ during HGD protocol could be one of the possible reasons for an observed reduced ability of astrocytes to take up glutamate via a $\mathrm{Na}^{+}$-dependent mechanism during hypoxia (Dallas et al. 2007).

\section{Conflict of Interest}

There is no conflict of interest.

\section{Acknowledgements}

The authors acknowledge the technical assistance of Dr. S. S. Mohan, Mrs. L. Jacob and Mrs. A. Al-Farhan. We acknowledge help of Dr. James Craig, Department of Biochemistry, in improving manuscript style and clarity. Financial support for this study was provided by Kuwait University Grant No MY01/08.

\section{References}

AL-BADER MD, EL-ABDALLAH AA, REDZIC ZB: Ontogenic profile of estrogen receptor alpha and beta mRNA and protein expression in fetal rat brain. Neurosci Lett 440: 222-226, 2008.

ALI S, LUTZY, BELLOCQ JP, CHENARD-NEU MP, ROUYEN R, METZEGER D: Production and characterization of monoclonal antibodies recognising defined regions of the human oestrogen receptor. Hybridoma 12: 391405, 1993.

BILlECI AM, PACIARONI M, CASO V, AGNELLI G: Hormone replacement therapy and stroke. Curr Vasc Pharmacol 6: 112-123, 2008.

BONDAR G, KUO J, HAMID N, MICEVYCH P: Estradiol-induced estrogen receptor-alpha trafficking. J Neurosci 29: 15323-15330, 2009.

BROUGHTON BR, REUTENS DC, SOBEY CG: Apoptotic mechanisms after cerebral ischemia. Stroke 40: e331e339, 2009.

CHAO XD, FEI F, FEI Z: The role of excitatory amino acid transporters in cerebral ischemia. Neurochem Res 35 : 1224-1230, 2010.

CHO J, BAHNA J, PARK M, AHNB W, LEE YJ: Hypoxic activation of unoccupied estrogen-receptor-alpha is mediated by hypoxia-inducible factor-1 alpha. J Steroid Biochem Mol Biol 100: 18-23, 2006.

CHO J, KIM D, LEE S, LEE Y: Cobalt chloride-induced estrogen receptor alpha down-regulation involves hypoxiainducible factor-1alpha in MCF-7 human breast cancer cells. Mol Endocrinol 19: 1191-1199, 2005.

DALLAS M, BOYCOTT HE, ATKINSON L: Hypoxia suppresses glutamate transport in astrocytes. J Neurosci 27: 3946-3955, 2007.

DIRNAGL U, IADECOLA C, MOSKOWITZ MA: Pathobiology of ischaemic stroke: an integrated view. Trends Neurosci 22: 391-397, 1999.

DOLMAN D, DRNDARSKI S, ABBOTT NJ, RATTRAY M: Induction of aquaporin 1 but not aquaporin 4 messenger RNA in rat primary brain microvessel endothelial cells in culture. J Neurochem 93: 825-833, 2005.

DUBAL DB, KASHON ML, PETTIGREW LC, REN JM, FINKLESTEIN SP, RAU SW, WISE PM: Estradiol protects against ischemic injury. J Cereb Blood Flow Metab 18: 1253-1258, 1998.

DUBAL DB, RAU SW, SHUGHRUE PJ, ZHU H, YU J, CASHION AB, SUZUKI S, GERHOLD LM, BOTTNER MB, DUBAL SB, MERCHANTHALER I, KINDY MS, WISE PM: Differential modulation of estrogen receptors (ERs) in ischemic brain injury: a role for ERalpha in estradiol-mediated protection against delayed cell death. Endocrinology 147: 3076-3084, 2006. 
DUBAL DB, ZHU H, YU J, RAU SW, SHUGHRUE PJ, MERCHENTHALER I, KINDY MS, WISE PM: Estrogen receptor alpha, not beta, is a critical link in estradiol-mediated protection against brain injury. Proc Natl Acad Sci USA 98: 1952-1957, 2001.

HABERG A, QU H, HARALDSETH O, UNSGÅRD G, SONNEWALD U: In vivo injection of $\left[1-{ }^{13} \mathrm{C}\right] \mathrm{glucose}$ and $\left[1,2-{ }^{13} \mathrm{C}\right]$ acetate combined with ex vivo ${ }^{13} \mathrm{C}$ nuclear magnetic resonance spectroscopy: a novel approach to the study of middle cerebral artery occlusion in the rat. J Cereb Blood Flow Metab 18: 1223-1232, 1998.

HABERG A, QU H, SAETHER O, UNSGÅRD G, HARALDSETH O, SONNEWALD U: Differences in neurotransmitter synthesis and intermediary metabolism between glutamatergic and GABAergic neurons during 4 hours of middle cerebral artery occlusion in the rat: the role of astrocytes in neuronal survival. J Cereb Blood Flow Metab 21: 1451-1463, 2001.

HALL ED, PAZARA KE, LINSEMAN KL: Sex differences in postischemic neuronal necrosis in gerbils. $J$ Cereb Blood Flow Metab 11: 292-298, 1991.

HERTZ L: Bioenergetics of cerebral ischemia: a cellular perspective. Neuropharmacology 55: 289-309, 2008.

HOSSMANN KA: Cerebral ischemia: models, methods and outcomes. Neuropharmacology 55: 257-270, 2008.

HUPPMANN S, ROMER S, ALTMANN R, OBLADEN M, BERNS M: 17beta-estradiol attenuates hyperoxia-induced apoptosis in mouse C8-D1A cell line. J Neurosci Res 86: 3420-3426, 2008.

IKEDA Y, NAGAI A: Differential expression of the estrogen receptors alpha and beta during postnatal development of the rat cerebellum. Brain Res 1083: 39-49, 2006.

JESMIN S, MOWA CN, MATSUDA N, SALAH-ELDIN AE, TOGASHI H, SAKUMA I, HATTORI Y, KITABATAKE A: Evidence for a potential role of estrogen in the penis: detection of estrogen receptor-alpha and -beta messenger ribonucleic acid and protein. Endocrinology 143: 4764-4774, 2002.

KAROVIC O, TONAZZINI I, REBOLA N, EDSTRÖM E, LÖVDAHL C, FREDHOLM BB, DARÉ E: Toxic effects of cobalt in primary cultures of mouse astrocytes. Similarities with hypoxia and role of HIF-1alpha. Biochem Pharmacol 73: 694-708, 2007.

KUO J, HARIRI OR, BONDAR G, OGI J, MICEVYCH P: Membrane estrogen receptor-alpha interacts with metabotropic glutamate receptor type 1a to mobilize intracellular calcium in hypothalamic astrocytes. Endocrinology 150: 1369-1376, 2009.

LI J, MCCULLOUGH LD: Effects of AMP-activated protein kinase in cerebral ischemia. J Cereb Blood Flow Metab 30: 480-492, 2010.

MEDA C, VEGETO E, POLLIO G, CHIANA P, PELliCCIARI C, MAGGI A: Oestrogen prevention of neural cell death correlates with decreased expression of mRNA for the pro-apoptotic protein nip-2. J Neuroendocrinol 12: 1051-1059, 2000.

MERGENTHALER P, DIRNAGL U, MEISEL A: Pathophysiology of stroke: lessons from animal models. Metab Brain Dis 19: 151-167, 2004.

PASQUALINI C, GUIVARCH D, BARNIER JV, GUIBERT B, VINCENT JD, VERNIER P: Differential subcellular distribution and transcriptional activity of sigmaE3, sigmaE4, and sigmaE3-4 isoforms of the rat estrogen receptor-alpha. Mol Endocrinol 15: 894-908, 2001.

PAWLAK J, BRITO V, KUPPERS E, BEYER C: Regulation of glutamate transporter GLAST and GLT-1 expression in astrocytes by estrogen. Brain Res Mol Brain Res 138: 1-7, 2005.

PETERSEN DN, TKALCEVIC GT, KOZA-TAYLOR PH, TURI TG, BROWN TA: Identification of estrogen receptor beta2, a functional variant of estrogen receptor beta expressed in normal rat tissues. Endocrinology 139: 10821092, 1998.

PFAFFL MW: A new mathematical model for relative quantification in real-time RT-PCR. Nucleic Acids Res 29: e45, 2001.

PREWITT AK, WILSON ME: Changes in estrogen receptor-alpha mRNA in the mouse cortex during development. Brain Res 1134: 62-69, 2007.

PRICE RH, LORENZON N, HANDA RJ: Differential expression of estrogen receptor beta splice variants in rat brain: identification and characterization of a novel variant missing exon 4. Brain Res Mol Brain Res 80: 260-268, 2000 . 
QIU C, SHAN L, YU M, SNYDERWINE EG: Steroid hormone receptor expression and proliferation in rat mammary gland carcinomas induced by 2-amino-1-methyl-6-phenylimidazo[4,5-b]pyridine. Carcinogenesis 26: 763-769, 2005.

REDZIC ZB, MALATIALI SA, AL-BADER M, AL-SARRAF HA: Effects of hypoxia, glucose deprivation and recovery on the expression of nucleoside transporters and adenosine uptake in primary culture of rat cortical astrocytes. Neurochem Res 35: 1434-1444, 2010.

RIST RJ, ROMERO IA, CHAN MW, COURAUD PO, ROUX F, ABBOTT NJ: F-actin cytoskeleton and sucrose permeability of immortalised rat brain microvascular endothelial cell monolayers: effects of cyclic AMP and astrocytic factors. Brain Res 768: 10-18, 1997.

ROMERO IA, LISTER T, RICHARDS HK, SEVILLE MP, WYLIE SP, RAY DE: Early metabolic changes during mDinitrobenzene neurotoxicity and the possible role of oxidative stress. Free Radic Biol Med 18: 311-319, 1995.

RUSA R, ALKAYED NJ, CRAIN BJ, TRAYSTMAN RJ, KIMES AS, LONDON ED, KLAUS JA, HURN PD: 17beta-estradiol reduces stroke injury in estrogen-deficient female animals. Stroke 30: 1665-1670, 1999.

SATO K, MATSUKI N, OHNO Y, NAKAZAWA K: Estrogens inhibit l-glutamate uptake activity of astrocytes via membrane estrogen receptor alpha. $J$ Neurochem 86: 1498-1505, 2003.

SEMENZA GL: Oxygen-dependent regulation of mitochondrial respiration by hypoxia-inducible factor 1 . Biochem $J$ 405: 1-9, 2007.

SHUGHRUE PJ, LANE MV, MERCHENTHALER I: Comparative distribution of estrogen receptor-alpha and -beta mRNA in the rat central nervous system. J Comp Neurol 388: 507-525, 1997.

TAYLOR SE, MARTIN-HIRSCH PL, MARTIN FL: Oestrogen receptor splice variants in the pathogenesis of disease. Cancer Lett 288: 133-148, 2010.

TOUNG TJ, TRAYSTMAN RJ, HURN PD: Estrogen-mediated neuroprotection after experimental stroke in male rats. Stroke 29: 1666-1670, 1998.

VERDIER F, CHRÉTIEN S, BILLAT C, GISSELBRECHT S, LACOMBE C, MAYEUX P: Erythropoietin induces the tyrosine phosphorylation of insulin receptor substrate-2. An alternate pathway for erythropoietin-induced phosphatidylinositol 3-kinase activation. J Biol Chem 272: 26173-26178, 1997.

WILSON ME, WESTBERRY JM: Regulation of oestrogen receptor gene expression: new insights and novel mechanisms. J Neuroendocrinol 21: 238-242, 2009.

WILSON ME, WESTBERRY JM, PREWITT AK: Dynamic regulation of estrogen receptor-alpha gene expression in the brain: a role for promoter methylation? Front Neuroendocrinol 29: 375-385, 2008.

YI JM, KWON HY, CHO JY, LEE YJ: Estrogen and hypoxia regulate estrogen receptor alpha in a synergistic manner. Biochem Biophys Res Commun 378: 842-846, 2009. 